Florence, 5 Mars, $188 \mathrm{I}$

A propos du déplacement projeté des collections botaniques du Musée d'Histoire Naturelle de Florence.

Lorsqu'au mois de Mai de l'année 1874 un grand nombre de botanistes de toutes les parties du monde se trouvirent réunis à Florence, dans les salles des Collections botaniques fondéts par feu le professeur Parlatcre, M. le professeur Alphonse de Candolle fit observer "qu'une des choses les plus remarquables s'imposant à l'attention des membres du Congiès, était le Musée butanique, avec ses salles amples et commodes, ou avaient lieu les séances du Congrès." ("Actes du Congrès Botanique international, tenu à Florence au mois de Mai 1874 ," pag. 220.)

Personne, alors, n'eût soupçonné que ce qui avait été jugé digne d'admiration par les howmes les plus compétents, serait déclaré mauvais et condamné à un bouleversement radical sept ans à peine après que ces paroles mémorables avaient été pro noncées. Pour justifier l'abandon du Musée actuel, on prétexte l'inconyénient qu'il y a pour les étudiants fréquentant les cours de l'Institut des Etudes surérieures, place St. Marc, d'avoir à se rendre, four une autre partie de ces cours, au Musée de Via Romana; et, afin de centraliser les édifices affectés aux étucies, on ne pense à rien moins quà opérer le déménagement des collections botaniques et à abandonner le jardin du Musée, avec toutes ses serres et annexes. En revanche, on parle de rendre à son ancien usage le modeste Jardin des Simples, situé à proximite du nouvel emplacement destiné aux herbiers. Mais a-t-on examiné si ce transport est réalisable, avantageux, et si le nouveau local de la place St. Marc, destiné à la Botanique, est adapté ou non à recevoir les herbiers et les autres collections ?

Or ce local n'est autre que le bâtiment des anciennes écuries des Grands Ducs de Toscane, occupées plus tard par la cavalerie italienne. Pendant une série non interrompue de près de trois cents années, ces écuries ont logé des chevaux en très-grand nombre, et c'est là que l'on se propose de colloquer des collections de plantes, d'un prix inestimable, et si faciles à se détériorer sous l'influence de l'humidité ! Il e:t vrai qu'en sacrifiant d'énormes sommes four reconstruire l'édifice à peu près de fond en comble, on ferait peut-être disparaître les traces du long usage auquel il a servi ; mais il est permis de se demander si, même dans ce cas, on obtiendrait jamais des salles comparables à celles du Musée actuel, soit en beauté, soit en salubrité, soit en solidité

Ce projet étant soutenu et sur le point.d'être mis à exécution par des personnes resfectables, mais étrangères à la Science et par conséquent incompétentes, nous Soussignés, amis de la Botanique résidents à Florence, crojons de notre devoir, dans l'intérêt des collections, de protester contre ce déplacement, et, afin de donner plus de poids à notre protestation, nous invitons les Botanistes qui se sont tı ouvés à Florence lors du Congrès de I874, ainsi que tous ceux qui connaissent les salles actuellenient affectées aux collections de plantes, à joirdre leurs voix à la nôtre pour emfêcher qu'on ne mette à exécution un projet que nous croyons hautement préjudiciable à nos plus chères étıdes.

Nous prions en conséquence les Botanistes italiens et étrangers de vouloir bien employer leur influence afin que le projet en question soit abardonné, et que les sommes, dès à-présent destinées à une cuvre inopportune et risquée, soient de préférence employées à augmenter le matériel scientifique du Musée actuel, par l'achat de collections de plantes vivantes et desséchées (surtout de plantes cryptogames) et d'ouvrages manquant à notre bibliothèque botanique et à acquérir les armoires et élagères, nécessaires pour placer et mettre en ordre une immense quantité de paquets d'herbier, actuellement sans emploi et inutiles anx études, ainsi qu'à adapter les serres du Jardin botaniqe aux exigences modernes, en commençant par y faire les réparations reconnues de première nécessité.

(Signé)

A. B. ARCHIBALD
D. BARGELLINI
ODOARDO BECCARI
ANTONIO BIONDI
EMANUELE G. FENZI
ENRICO GROVES
EMILIO LEVIER

\section{E. MarCuCCI}

Ugolino Martelli

VINCENZO RICASOLI

RICCARDO RICCI

NICCOLÒ RIDOLFI

S. SOMMIER

P. DE TChIHATChEF

\section{Barometer Pumps}

Communications from Mr. Sprengel have been published, in which he has defended his claim to be the inventor of the mercury barometer-pump. As long as he confined himself to this claim I had no right to interfere, but by his letter in your previous number (vol. xxiv. p. 53) he claims to be the inventor or father of all kinds of barometer-pumps. His right to this claim I disfute ; for in May, I847, I ot tained a patent for improvements in sugar-refining, ore of $\mathrm{n}$ hich is the conversion of a vacuum-pan into a large barometer by placing under a common vacuum pan a long pipe in a perpendicular position, which acts as a pump whereby the sugar is taken out of the pan by its own weight in the long pipe, and thereby the vacuum in the pan is not destroyed, and the process of sugar-boiling is carried on continuously. The syrup to be boiled is added in the pan above, while the boiled sugar is taken out below through the barometer-pump. The specification of my patent was published in patent journals in London in 1847 , and it is possible that Mr. Sprengel took the idea of his mercury barometer-pump from my sugar barometer pump. But at all everts Mr. Sprengel was nct the first inventor of a barometer-pump. I claim that honour.

JAMES JOHNSTONE

Experiment Rocms, No. I, James Square, Edinburgh, May 21

The Hutton Collection of Fossil Plants

Ir has only within the last few days come to my knowledge (indeed only to-day authoritatively) that the Hutton Collection of Fossil Plants, at present deposited in the Museum of the Natural History Society of Northumberland and Durbam, at Newcastle, had been naned by the curator, Mr. Richard Howse, prior to the compiling by my: elf of a Catalogue of the Collecticn, published in 1878 by the North of England Institute of Mining and Mechanical Engineers. The labels on the specimens, referred to in the Catalogue, were therefore Mr. Howse's, and not, as I until now imagined, either William Hutton's original ones, or mere copies of them.

Moreover an unsigned MS. list of the specimens in the Collec. tion, agreeing with the labels, with which I was furniched by the Mining Institute, and which was used freely by me in drawing up the Catalogue, must now be regarded as the result of much time and labour spent by Mr. Howse in identifying and naming the whole of the Hutton Collection.

I trust you will allow me space in your paper to acknowledge now what I should have made a point of acknowledging in the preface to the "Catalogue," had I been made acquairted with the facts of the cas e at the time.

G. A. LEBOUR

College of Physical Science, Newcastle-upon-Tyne, May I8

\section{"How to Prevent Drowning"}

Mr. MarCORMaC's valuable article induces me to call attention to a prevalent error.

Almost every treatise on swimming tells the beginner that every one can float without exertion. Even Mr. MacCormac seems to impiy that "lying quite still with the mouth shut and the head thrown well back in the water "is enough to insure any one against sinking. Now this may possibly be true for most men, tut certainly not for all. I am a practiced swimmer, fond of the water, and have of ten tried. Going through all the orthodox motions of the deep breath, the folded arms, and the head thrown back, I go down instantly. This is in fresh water; in salt I believe I can just float, but have seldom had a good opportunity of trying. The fact is that men are very different in buoyancy: I have seen a man float motionless with head and shoulders out of the water. Others may be even denser than I am. Most men believe themselves capable of coolness and presence of mind. They should remember that these will neither supersede the art of swimming ror alter the laws of gravity.

St. John's College, Cambridge

\section{The Effects of Pressure on the Germination and Growth} of Plants

THE following experiments may be of interest to vegetable physiologists:-On April 7, at II p.m., two sets of mustard. seeds-five in each set- were sown on fieces of moist cotton. wool, arranged as follows:-One piece was placed in a small bottle, which was then secured to the curved ex!remity of a glass tube, into the long arm of which mercury was poured till a height of forty-five inches was reached above the level of the metal in the shorter arm. The seccnd piece, with its seeds, was placed in an exactly similar bottle, the neck of which was then made to dip benealh mercury, the bottle, of course, like the one soldered on to the tube, being inverted. This bottle was then placed beside the first. 